\title{
O PENSAMENTO CRÍTICO E CRIATIVO DE MAURÍCIO TRAGTENBERG
}

\author{
Por José Henrique de Faria \\ Professor Doutor Titular da Universidade Federal do Paraná; Visiting Professor at the University of Michigan. \\ E-mail: faria@umich.edu
}

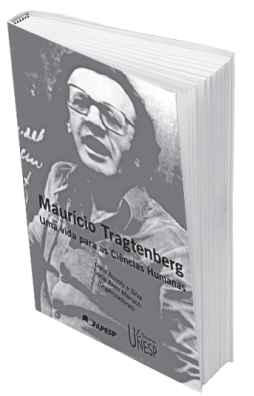

\section{MAURÍCIO TRAGTENBERG: UMA VIDA PARA AS CIÊNCIAS HUMANAS}

De Doris Accioly Silva e Sonia Alem Marrach (Orgs.)

São Paulo: Editora da Unesp, 2001.

Homenagear Maurício Tragtenberg sempre me parece que é necessário e, ao mesmo tempo, um tributo cujo valor, por maior que seja, tem a possibilidade de ser menor do que deveria. Quem teve a oportunidade de conhecê-lo sabe que há sempre mais do que dele se pode dizer. "Maurício Tragtenberg: uma vida para as Ciências Humanas", organizado por Doris Accioly e Silva e Sonia Alem Marrach é, mais do que uma homenagem, um reconhecimento. Resultado da "Jornada Maurício Tragtenberg" realizada na Unesp /Marilia em agosto de 1999, o livro apresenta um conjunto de $28 \mathrm{de}$ poimentos /análises sobre a vida e a obra desse que foi, sem dúvida, um dos mais criativos, ousados e profícuos intelectuais críticos do Brasil.

Ao ler, com atenção, cada um dos textos que compõem esse oportuno e bem-vindo livro, fui tomado de emoção. Cada depoimento /análise parece ser uma interpretação de uma das facetas de Maurício, mas todos mostram um mesmo intelectual, um mesmo homem. Cada texto foi, para mim, de difícil leitura: em nenhum deles fui capaz de ir do começo ao fim sem ser interrompido por lembranças e por reflexões, nem todas exatamente acadêmicas, pois é inevitável que surjam replays de conversas, exposições, debates. Por isso, mesmo que o livro se apresente em três partes, é impossível separar, em Maurício, o ser humano do intelectual, o pensamento da ação, a generosidade do rigor.

Conheci Maurício Tragtenberg em Porto Alegre, em abril de 1978. Em poucos minutos percebi que ele era o guardião de um tesouro e, assim, coloquei-me nesta aventura, que até hoje vivo, de desvendar os mistérios do que parece ser solidamente dado, de não me contentar com as verdades teóricas definitivas, de não me deixar apanhar pelo dogmatismo. Maurício tinha uma chave para esse percurso: colocar para conversar os que a academia tradicional havia separado. Ao ler os depoimentos /análises, vejo que minha percepção aparece em todos os textos, tal como aconteceu na homenagem prestada a Maurício na FGV-EAESP.

$\mathrm{Na}$ primeira parte do livro, encontramos Maurício Tragtenberg, como o violinista, no telhado; não apenas o da Rua Catumbi, mas onde habitam seus amigos, alunos, admiradores e críticos. Sonia Marrach, Lélia Abramo, Antônio Cândido, Michael Löwy, Fernando de Carvalho, Evaldo Auraro Vieira, Edgar de Assis Carvalho e Antonio Valverde falam do Maurício que conheceram, colocando-nos diante do homem. Os depoimentos de Evaldo Vieira e Antonio Valverde são para mim particularmente muito próximos, pois se referem a períodos e observações conhecidas. Todos tratam de situações que revelam a trajetória e as particularidades que o fizeram um 
brilhante outsider (Valverde), alguém que viveu "a honradez com inteligência" (Vieira), que soube "dar o salto" (Abramo), um "servidor da verdade" (Cândido) que "se destacou pela coerência política e intelectual" (Löwy), "um espírito crítico e sensível" (F. de Carvalho), que "apostava em um mundo mais livre e menos recalcado (E. de A. Carvalho).

A segunda parte do livro é dedicada à análise das contribuições de Tragtenberg para as Ciências Humanas, que compreendem suas concepções acerca do socialismo e da autogestão, tendo a solidariedade como pano de fundo (Doris Accioly e Silva); de sua identificação com Rosa Luxemburgo e sua (injusta) crítica a Herbert Marcuse (Isabel Loureiro); de suas reflexões críticas à burocracia, à administração e à lógica capitalista (Ricardo Antunes); de seu investimento contra a "delinqüência acadêmica", em que, em defesa de suas convicções que incluem o anarquismo, "lança um petardo certeiro na universidade brasileira" (Edson Passetti); de seu pensamento heterodoxo fundamentado em uma prática que escapou dos enquadramentos burocráticos (Lúcia Bruno); de sua prática literária que não poupava críticas a qualquer forma de autoritarismo (Antonio Ozaí da Silva); do acadêmico diferenciado, fora do percurso de rotina, sem pergaminhos de escola, um judeu sem templo, um militante sem partido, um intelectual sem cátedra (Paulo-Edgar Almeida Resende); do combatente pela educação, cujos compromissos eram as idéias e os princípios (Agueda Bernadete Bittencourt Uhle) que exigiam a responsabilidade social dos pesquisadores, dos quais Maurício cobrava a finalidade do conhecimento, cuja ausência se constitui em fator de delinqüência acadêmica (Raquel Pereira Chainho Gandini); do "descolonizador" da história, que trabalhou com Kantilya e clássicos orientais pouco lidos no Ocidente (Paulo Ribeiro da Cunha); de um socialista libertário que buscava no diálogo de Marx com Weber a crítica da infra-estrutura e da superestrutura do capitalismo (Pedro Roberto Ferreira); do leitor impaciente quanto aos fundamentos das harmonias administrativas entre capital e trabalho (Felipe Luiz Gomes e Silva). Enfim, de uma obra que provoca reflexões sobre a ausência da política no contexto contemporâneo (Franklin Leopoldo e Silva).

A terceira parte do livro trata daquilo que foi a mais importante característica de Maurício: a coerência entre teoria e prática, sua práxis revolucionária. Marinice Fortunato fala do professor interessado nos alunos, da empatia, da humildade e da solidariedade social; José Carlos Orsi Monel fala da solidariedade não sofística de Maurício com os movimentos populares de cunho autogestionário, de seu engajamento não só teórico, mas de sua ação; Iolanda Toshie Ide fala sobre solidariedade de gênero e do compromisso de Maurício com a luta dos direitos humanos, tendo em Rosa Luxemburgo o exemplo entre teoria e prática; Liliana Rolfsen Petrilli Seguini fala do amigo, do intelectual intransigente, da pessoa generosa e irreverente e do compromisso ético de manter vivo seu pensamento; Célia Aparecida Martins fala da voz não silenciada, que não foi destruída por nenhuma objetivação ou cotidianização alienadora; José Carlos Brito fala das lutas autogestionárias, tendo por referência o ABC paulista e, junto com Cleodon Silva, lembra o interesse e o envolvimento de Maurício na linha de frente do combate em favor das livres e independentes formas de organização.

Ler esse livro de depoimentos e análises sobre Maurício Tragtenberg é ler uma história de vida que parece rara nos dias de hoje. No momento em que o "centrismo" político toma conta da sociedade, em que o conformismo abraça a academia, em que a crítica é tratada como "denuncismo" diante dos "pragmatismos solucionistas", torna-se necessário resgatar a obra de Tragtenberg como exemplo de uma luta que não faz concessões a qualquer tipo de violência, pois, como ensina Hanna Arendt, "quando tudo é permitido, tudo é possível".

Quando tantos e tão importantes professores se unem para homenagear um outro professor, em uma realidade que não é dada a esse tipo de reconhecimento e delicadeza entre pares, normalmente voltados a suas autopromoções, é porque o homenageado é de tal sorte referenciado que transcende à própria lógica do "complô de belas almas". O livro que resulta dessa homenagem talvez fosse encarado pelo homenageado como desnecessário ou exagerado, mas para os que conheceram Maurício Tragtenberg e para os que não o conheceram e precisam conhecer, é oportuno e preenche um vazio na qualificação daquele que foi um dos mais importantes intelectuais críticos brasileiros e que pertence para sempre à história do pensamento original. O livro é, na verdade, um grande presente que as organizadoras e os autores ofereceram para todos os que acreditam no pensamento original, crítico e criativo.

Ao final, divido meus sentimentos com Passetti a respeito dos eventos comemorativos e suas finalidades. Há, nesses casos, sempre o risco de uma certa prática televisiva em que o homenageado, rumando para o "indestrutível", já possui a reportagem pronta antes do fato final. A qualidade dos depoimentos e reflexões constantes de "Maurício Tragtenberg: uma vida para as Ciências Humanas" é, de fato, uma antítese da festa dos culpados. 